\title{
PQRST TECHNIQUE TOWARD READING COMPREHENSION OF THE SECOND GRADE STUDENTS AT SMAN 1 KOTA JAMBI
}

\author{
Dewi Syafitri ${ }^{1}$ \\ STKIP-PGRI Lubuklinggau \\ dewisyafitristkipllg@gmail.com ${ }^{1}$ \\ Submit, 08-11-2017 Accepted, 30-12-2017 Publish, 30-12-2017
}

\begin{abstract}
This research is aimed to investigate whether or not there is any significant effect of PQRST technique toward reading comprehension of second graders at SMAN 1 Kota Jambi.Preview, question, read, summary and test labeled PQRST is one of language teaching technique in reading comprehension. This technique can be used to solve students' difficulties in comprehend the text and also can help the students to deepen their understanding of the text. The subjects were students of grade XI of SMAN 1 Kota Jambi. XI IA 1 was assigned as the experimental group and XI IA 2 was assigned as control group. The cluster sampling technique was used in this research. The design of this research is an experimental research to find out the cause and effect relationship between two variables. There are two data used in this research. The first data is pre-test and the second is post-test. After the data were collected, the researcher used t-test analysis to see the significant difference between two variables. The result of this research showed that t-test value was 3.15, at the level of significance 0.05 with $\mathrm{df} 60$, the value of $\mathrm{t}$-table was 2.00. it is known that t-test value was bigger than $\mathrm{t}$-table indicated the research hypothesis (H1) was accepted where there is significance difference in students, reading comprehension between those who were taught by using PQRST technique and those who were taught without using PQRST technique. In summary, PQRST technique can help the students to comprehend the reading text well.
\end{abstract}

Keywords: reading comprehension, PQRST technique

\section{INTRODUCTION}

Reading is one of the skills that should be mastered competently by senior high school students at informational level and should be taught appropriately by the teachers who have a prominent function in the curriculum succession. One of the examples is cited by Byrd (1998) who explains that in teaching reading the teacher should be selective in providing materials for the student in the lesson. The teacher can supply resources by referring everyday reading material such as "train schedule, news paper article, and travel and tourism web sites" to increase student knowledge, particularly in helping them reach communicative competence. 
Teaching English especially reading in Indonesia emphasizes on comprehension. The teachers usually use three-phase activity technique in teaching reading. This technique includes pre-reading, whilst reading and post reading (Fachrurrazy, 1993:3). There are several techniques can be used to comprehend the text. One kind of techniques in comprehend the text proposed by researcher is PQRST technique. One technique used by structured students to keep them on track is the PQRST technique. This technique prioritizes the information in a way that relates directly to how they will be asked to use that information in an exam. The technique can also be modified to suit any particular form of learning in most subjects. It allows more accurate timing of work rather than the student having to decide how much time to attribute to a topic (http://study_skill.htm). One of the best techniques for improving memory from reading is called PQRST technique (preview, question, read, summary, and test). The technique is intended to improve students' abilities to study and remember material presented in the text books.

The researcher used this technique in reading comprehension because this technique solve the students' difficulties in comprehend the text and also it could help the student to deepen their understanding of the text through each step of PQRST technique.

The researcher is interested in conducting a quantitative study by coming across a senior high school in the Jambi. The focus of study is students of SMAN 1 Kota Jambi. The research question of this study is "Is there any significant effect of PQRST technique toward reading comprehension of second grade students at SMAN 1 Kota Jambi?"

\section{LITERATURE REVIEW}

Teaching English especially reading in Indonesia emphasize on comprehension. The teacher is suggested using three-phase activity procedure in teaching reading. This procedure includes pre-reading, whilst reading and post reading (Fachrurrazy, 1993). Pre-reading activity is used to introduce the topic that teacher will be taught and give motivation to the student to learn it. This activity can fill by giving some questions that related to the topic, show the pictures and ask the student to guess the topic that they will learn, or introduce the title of the text and invite the students to discuss the topic. Whilst reading activity is core activities to get comprehension content of the text. This activity divided into two parts, they are surface problem and deep problem. For surface problem include factual questions about content of the text, scanning and skimming or complete the table, sentences or list based on the text. For deep activity include difficult questions such as wh-question (why, where, how, etc), or question which its implied answer in the reading text, give true false questions, and ask the student to give the reason of their answer choice. Post reading activity meant as last activity that relate to the content of reading text, for example speaking or writing about something that relate to the topic. 
Preview, Question, Read, Summary and Test labelled PQRST is one of language teaching technique in reading comprehension. PQRST researched by Thomas and Robinson (1982), Spache and Berg (1978), and Robinson (1970) has demonstrated that a simple study technique applied to reading a book significantly improves understanding and memory. The technique takes its name from the first letter of the five steps that one follows - preview, question, read, self-recitation, and test.

According to Fazel (1993:1[Online]) one technique used by structured students to keep them on track is the PQRST technique. This technique prioritizes the information in a way that relates directly to how they will be asked to use that information in an exam. The technique can also be modified to suit any particular form of learning in most subjects. It allows more accurate timing of work rather than the student having to decide how much time to attribute to a topic.

In applying the PQRST technique, the teacher takes responsibility for the stages labeled preview and read (in this case in lecture classes) and leaves the element of student-teacher interaction for the stages labeled question, Summary, andtest(http://www.uem.es/myfiles/pageposts/jiu/jiu2006/archivos/PDAA/PDAA 24.pdf.). Preview, Question, Read, Summary and Test (PQRST) derives its name from the five phases, it advocates for studying chapter/ text material in a text book.

Preview -- Some steps that the students can do in previewing the material are: to survey the chapter/text to get an idea of what's ahead. This will prepare their brain to think in terms of that subject. To note the chapter title, it may contain the main idea or theme. Read the summaries of the chapter to get a good overview of the material. To the headings and sub-headings, any underlined or italicized words and anything else that looks important. To look at any graphs, charts or pictures. These could emphasize important information. In this research, the researcher modified this step. The students will preview the title, the first paragraph and also the last paragraph to get the description about the content of the text.

Question -- In this second step, students are demanded to be creative by making question while reading. They also, can read the question at the end of the text but they do not answer it directly. They can find the answers while they have their activity later. The students can create questions from headings or an important idea when they are reading the materials.

Read -- The third step is reading itself. Students can actually read the text. Do it carefully, think about the meaning and relate this to other things students know about this and similar topics. Students can do some underlining or highlighting of key words, but don't overdo it. If students want to take notes, read the whole section first, and then summarize it later. 
Summary -- In this step, students summarize for themselves what they just read. This allows students to check their understanding of the material, and will aid retention of it. Without looking at the text, recite the main headings and the main idea under each. Then - still without looking - tell yourself in a sentence or two what you read. Finally, scan over the section quickly to pick up any essential points you may have missed.

Test -- The last step of PQRST is test. Students make certain that they know and remember what they read. Then, they answer the question of the text.

\section{RESEARCH METHOD}

The method used in this research was quasi experimental method. Salkind (1991:232) pointed out that in quasi experimental research, the hypothesis cause of the differences that might be observed between groups had already occurred. This design was selected because it was impossible to do randomization and assign the subjects to several different groups. Beside that, it was hard to do because the school has fixed system that cannot be changed such as number of students, time of study, and number of classes.

In this research, the researcher used the nonequivalent control-group design. The design was shown as follow (Salkind 1991:234):

Table 1. The Nonequivalent Control-Group Design

\begin{tabular}{clll}
\hline Experimental group & Pre-test & Treatment & Post-test \\
\hline Control group & Pre-test & & Post-test \\
\hline
\end{tabular}

The pre-test was administered to both of groups. The experimental group was taught by using PQRST technique and the control group through three phase technique. Finally, the posttest was administered to both of group. There were three steps in doing this research. The first was giving pre-test to the students. Second was a treatment in which there were 8 meetings including pre and post test to give treatment. In the last meeting, the student was given post-test in order to know students' achievement after the treatment given. The result of pre-test and post-test after giving the treatment was compared. This comparison showed the using of treatment whether it is successful or not. 


\section{Population}

According to Nunan (1993:27) Population is all cases, situations, or individual who share one or more characteristics. The population of this study is all the second grade students of SMAN 1 Kota Jambi in academic year 2009/2010 with total number 220 students. Table 2 shows the population of the study.

Table 2. The Population of the Study

\begin{tabular}{ccc}
\hline NO & Classes & Number of Students \\
\hline 1 & XI IA 1 & 31 \\
\hline 2 & XI IA 2 & 31 \\
\hline 3 & XI IA 3 & 32 \\
\hline 4 & XI IA 4 & 32 \\
\hline 5 & XI IA 5 (CI) & 14 \\
\hline 6 & XI IS 1 & 40 \\
\hline 7 & XI IS 2 & 40 \\
\hline
\end{tabular}

\section{Sample}

According to Salkind (1991:31), a sample is representative of only part of population, but is used to generalize back to the population. In this study, the cluster sampling is used. The cluster sampling is sampling in which groups, not individuals, are randomly selected. All the members of selected groups have similar characteristics (Gay 1992:132). The sample of this research was taken from two classes whose English achievement was the same by comparing the previous semester scores. The results were as the sample of the study. To determine the experimental group and control group, the researcher flipped a coin. Table 3 shows the sample of the study.

Table 3. The Sample of the Study

\begin{tabular}{cccc}
\hline No & Group & Classes & Total \\
\hline 1 & The Experimental Group & XI IA 1 & 31 \\
\hline 2 & The Control Group & XI IA 2 & 31 \\
\hline \multicolumn{3}{c}{ Total } & 62 \\
\hline
\end{tabular}

\section{Variables}

In doing the research, variables have meaning in the content of the study, since they represent something that can distinguish them from other components being studied. Ary et al (2002:34) state that variable is a construct or a 
characteristic that take on different value or scores. The study has two variables. They are dependent and independent variables. Here, the treatment of teaching by using PQRST technique served as the independent variable and the students reading comprehension achievement served as the dependent variable.

\section{Data of the Research}

Data of this research is in form of quantitative data, which are students' scores of reading comprehension test. There were two data used in this research: pre-test and post-test score. In addition, the first data was used to see the score of reading comprehension test between experimental (before treatment) and control group while the second one was to see whether the improvement is significant or not thus it is tested by using t-test formula.

\section{Test Specification}

The specification both of pre-test and post-test is presented in the next table. The test is in the form of multiple choice items. There are 2 (two) reading texts. The first text consist of 10 (ten) questions and the second one consists of 7 (seven) questions. The total numbers of the test items are 34 items for pre-test and post-test. These questions represented in the element of reading comprehension, they are: 1) finding topic and main idea, 2) finding detail and factual information, 3) finding reference word, 4) fFinding vocabulary items

Table 4. Specification of Pre-test

\begin{tabular}{|c|c|c|c|}
\hline $\begin{array}{l}\text { Pre- } \\
\text { test }\end{array}$ & $\begin{array}{c}\text { Type of reading comprehension } \\
\text { question } \\
\end{array}$ & $\begin{array}{c}\text { Test } \\
\text { number }\end{array}$ & $\begin{array}{c}\text { The number of } \\
\text { item }\end{array}$ \\
\hline Passage & 1. Topic and main idea. & 1 & 1 \\
\hline \multirow[t]{3}{*}{1} & 2. Detail and factual information. & $2,3,4,5,6,7$ & 6 \\
\hline & 3. Reference word. & 8 & 1 \\
\hline & 4. Vocabulary items. & 9,10 & 2 \\
\hline Passage & 1. Topic and main idea. & 1 & 1 \\
\hline \multirow[t]{3}{*}{2} & 2. Detail and factual information. & $2,3,4$ & 3 \\
\hline & 3. Reference word. & 5 & 1 \\
\hline & 4. Vocabulary items. & 6,7 & 2 \\
\hline
\end{tabular}


Specification of Post-test

\begin{tabular}{|c|c|c|c|}
\hline $\begin{array}{c}\text { Post- } \\
\text { test }\end{array}$ & $\begin{array}{c}\text { Type of reading comprehension } \\
\text { question }\end{array}$ & $\begin{array}{c}\text { Test } \\
\text { number }\end{array}$ & $\begin{array}{c}\text { The number of } \\
\text { item }\end{array}$ \\
\hline Passage & 1. Topic and main idea. & 1 & 1 \\
\hline \multirow[t]{3}{*}{1} & 2. Detail and factual information. & $2,3,6,7,8,10$ & 6 \\
\hline & 3. Reference word. & 4 & 1 \\
\hline & 4. Vocabulary items. & 5,9 & 2 \\
\hline Passage & 1. Topic and main idea. & 1 & 1 \\
\hline \multirow[t]{3}{*}{2} & 2. Detail and factual information. & $2,3,6$ & 3 \\
\hline & 3. Reference word. & 5 & 1 \\
\hline & 4. Vocabulary items. & 7,4 & 2 \\
\hline
\end{tabular}

\section{Technique of Collecting Data}

In collecting the data, the test was used. Ary et al (2002:216) states "a test is stimuli presented to an individual in order to elicit responses on the basic of which numeral score can be assigned". In this study, the pre-test was used to find out the students' achievement of reading comprehension before the treatment. And the post-test was used to find out the students' achievement of reading comprehension after treatment. Multiple choices were the form of the test used in pre-test and post-test.

Both of data (pre-test and post-test) are obtained through reading comprehension test. The first data is got from pre-test that was given in the first meeting before treatment and the test was administered after treatment. The two tests were administered to see how much improvement of the students, comprehension score before treatment. The second data is obtained from post-test result. The post-test was administered once in both experimental and control group. The post-test was administered in the last meeting. The experimental group was taught by using PQRST technique while the control group was taught by using traditional technique.

Additionally, the number of the test is 17 questions. In the pre-test and post-test, the test consisted of two texts. The first text consisted of 10 questions and the second one 7 questions. The source of the test was adopted from Interlanguage English for senior high school student XI language study program and published by Pusat Perbukuan Depdiknas written by Joko Priyana. 


\section{Validity of the Test}

Validity is the quality of instrument doing what it is design to do (Salkind, 1991:109). The validity of the text was determined through content validity. Sugiyono (2008:182) stated that for instrument is a test, the validity can be measured by comparing between the content of the test and the subject is learned.

\section{Technique of Data Analysis}

The data obtained (students' reading comprehension score at pre-test and post-test result) were analyzed. Then post-test score for both of class, they can be interpreted based on scoring interpretation of students' achievement. Moreover, the score interpretation for post-test is adapted from Heaton and Nurgiantoro in Yuliana (2007:26) as follows:

Table 5. The Score Interpretation for the Students' Achievement

\begin{tabular}{cc}
\hline Score & Category \\
\hline $81-100$ & Very Good \\
\hline $61-80$ & Good \\
\hline $41-60$ & Fair \\
\hline $21-40$ & Weak \\
\hline $0-20$ & Poor \\
\hline
\end{tabular}

Then, the score of post-test form both classes which is automatically as the post-test data has tested by using t-test formula. It was done to see the significant differences between those groups. Here is the formula of t-test (Gay, 1992:442):

$$
\begin{array}{rlrl}
\boldsymbol{t} & =\frac{\overline{\boldsymbol{X}_{1}}-\overline{\boldsymbol{X}_{2}}}{\sqrt{\left[\frac{S S_{1}+S S_{2}}{\boldsymbol{n}_{1}+\boldsymbol{n}_{2}-{ }_{2}}\right]\left[\frac{1}{\boldsymbol{n}_{1}}+\frac{1}{\boldsymbol{n}_{2}}\right]}} \\
X_{1}=\frac{\sum X_{1}}{n_{1}} & X_{2}=\frac{\sum X_{2}}{n_{2}} \\
S S_{1} & =\sum X_{1}^{2}-\left(\frac{\sum X_{1}}{n_{1}}\right)^{2} & S S_{2}=\sum X_{2}{ }^{2}-\frac{\left(\sum X_{2}\right)^{2}}{n_{2}}
\end{array}
$$


Legends:

$\mathrm{t} \quad=$ the value of $\mathrm{t}$-calculated

$\mathrm{X} 1=$ the mean of experimental class

$\mathrm{X} 2=$ the mean of control class

SS1 = the variance of experimental class

SS2 = the variance of control class

$\mathrm{N} 1=$ the number of experimental class

$\mathrm{N} 2=$ the number of control class

In addition, the result of t-test was compared to t-table. If t-test value is higher than t-table, it means that there is significant difference on students' reading comprehension as they are taught by PQRST technique and those who are not. In other words hypothesis 1 is accepted. Vice versa, if it is lower than t-table, it means that PQRST technique does not have any significant effect on the second grade students' reading comprehension. Therefore, hypothesis 0 accepted.

\section{FINDING}

\section{The Result of the Pre-test and Post-test in the Experimental Group}

The result of the pre-test in the experimental group showed that the lowest score is 53 , the highest score is 88 and the mean score is 72.65 . In the post-test the lowest score is 65 , the highest score is 100 and the mean score is 83.71 . Table 7 shows the score distribution in the experimental group.

Table 6. The Distribution of Pre-test and Post-test Score in Experimental Group

\begin{tabular}{|c|c|c|c|c|c|}
\hline \multirow[t]{2}{*}{ Score } & \multirow[t]{2}{*}{ Category } & \multicolumn{2}{|c|}{ Pre-test } & \multicolumn{2}{|c|}{ Post-test } \\
\hline & & Frequency & Frequency & Percentage & Percentage \\
\hline $81-100$ & Very Good & 7 & $22.58 \%$ & 21 & $67.74 \%$ \\
\hline $61-80$ & Good & 18 & $58.06 \%$ & 10 & $32.25 \%$ \\
\hline $41-60$ & Fair & 6 & $19.35 \%$ & - & - \\
\hline $21-40$ & Weak & - & - & - & - \\
\hline $0-20$ & Poor & - & - & - & - \\
\hline \multicolumn{2}{|c|}{ Total } & \multicolumn{2}{|c|}{31} & \multicolumn{2}{|c|}{31} \\
\hline
\end{tabular}

From the table 6 , the pre-test result in experimental can be seen that there are 7 students $(22.58 \%)$ are in very good category, 18 students $(58.06 \%)$ are in good category, 6 students (19.35\%) are in fair category and no student is in weak 
and poor category. For post-test result, it can be seen from the table 7, in experimental group there are 21 students $(67.74 \%)$ are in very good category, 10 students $(32.25 \%)$ are in good category, and no students is in fair, weak and poor category.

\section{The Result of the Pre-test and Post-test in the Control Group}

The result of pre-test in the control group showed that the lowest score is 53, the highest score is 82 and the mean score is 69.06. In the post-test the lowest score is 53 , the highest score is 94 and the mean score is 75.94 . The table 8 shows the score distribution in the control group.

Table 7. The Distribution of Pre-test and Post-test Score in Control Group

\begin{tabular}{|c|c|c|c|c|c|}
\hline \multirow[t]{2}{*}{ Score } & \multirow[t]{2}{*}{ Category } & \multicolumn{2}{|c|}{ Pre-test } & \multicolumn{2}{|c|}{ Post-test } \\
\hline & & Frequency & Frequency & Percentage & Percentage \\
\hline $81-100$ & $\begin{array}{l}\text { Very } \\
\text { Good }\end{array}$ & 6 & $19.35 \%$ & 15 & $48.39 \%$ \\
\hline $61-80$ & Good & 16 & $51.61 \%$ & 12 & $38.71 \%$ \\
\hline $41-60$ & Fair & 9 & $29.03 \%$ & 4 & $12.90 \%$ \\
\hline $21-40$ & Weak & - & - & - & - \\
\hline $0-20$ & Poor & - & - & - & - \\
\hline \multicolumn{2}{|c|}{ Total } & \multicolumn{2}{|c|}{31} & \multicolumn{2}{|c|}{31} \\
\hline
\end{tabular}

From the table 7, in can be seen that the pre-test in control group, 6 students $(19.35 \%)$ are in very good category, 16 students $(51.61 \%)$ are in good category, 9 students $(29.03 \%)$ are in fair category and no student is in weak and poor category. For post-test result, it can be seen from the table 8 , in the control group there are 15 students $(48.39 \%)$ are in very good category, 12 students $(38.71 \%)$ are in good category, 4 students $(12.90 \%)$ are in fair category and no student is in weak and poor category.

\section{Data Analysis}

To know whether there is significant difference between experimental scores' and control group scores', t-test formula is applied. Based on the calculation, it was found that the value of t-test is 3.157. And then the value of $t$ table is 2.00 with the degree of freedom 60 and the level of confidence 0.05 . So, it concluded that the value of t-test was higher than value of t-table. 


\section{Hypothesis Testing}

From the data analysis, the hypothesis can be tested as follow:

Null hypothesis $\left(H_{0}\right)$ is rejected:

"The value of t-test was the less than the value of t-table"

Alternate hypothesis $\left(H_{1}\right)$ is accepted:

"The value of t-test was higher than the value of t-table"

On the basis of calculation, the $\mathrm{t}$-value of level significance 0.05 with $\mathrm{df}=$ $60(\mathrm{n} 1=\mathrm{n} 2-2)$ is 2.00 . The post-test result from both groups were tested by using $\mathrm{t}-$ test formula and from the calculation, the t-test result was 3.157. So it is clear that the value of t-test is higher than t-table, it means that there is significant effect of PQRST technique in reading comprehension. In other words, Alternate Hypothesis is accepted.

\section{DISCUSSION}

Based on the analysis, it is found that there is better improvement of group who were taught by PQRST technique and those who were not. This can be seen from pre-test result before treatment and post-test result after treatment in both of groups. Teaching reading by using PQRST technique in experimental group was more effective than using three phase technique in control group. It can also be seen from the difference between pre-test and post-test from both experimental and control as follows:

Table 8. The Mean of Pre-test and Post-test of Experimental and Control Group and Their Difference

\begin{tabular}{cccc}
\hline Class & Pre-test & Post-test & Difference \\
\hline Experimental & 72.64 & 83.70 & 11.06 \\
\hline Control & 69.06 & 75.93 & 6.87 \\
\hline
\end{tabular}

From the table 8 , in experimental group, the average of pre-test result is 72.64 and the average of post-test result is $83.70 \%$. The difference between pretest and post-test was 11.06. Hence, in the control group, the average of pre-test result is 69.06 and the average of post-test is 75.93 with the difference between pre-test and post-test is 6.87 . It clears that PQRST technique has significant effect on increasing students' reading comprehension. 
Preview, question, read, summary, test (PQRST) was given as the treatment in experimental group. Before the treatment was conducted in this group, the students only read the text and then answer the question and did not really understand about the content of the text. These behaviors changed dramatically during the treatment. The students could comprehend the text well, could retell the story in oral or written by using their own words and answer the question without seeing the text again because they have made a summary of the text before and also they did not spend much time to comprehend a reading text so they could save the time and organized the time well. So, it is concluded that PQRST could encourage learning reading text.

However, in the control group, because they were learning reading with the similar way they knew before, they were likely bored. There was no new motivations happened in this group, because they did not really understand about the content of the text and also they needed much time in answer the question of the text.

In experimental group, before the treatment was given for this group, the pre-test result showed that the lower category was fair and the highest category was very good with six students $(19.35 \%)$ were in fair category and seven students $(22.58 \%)$ were in very good category. But after treatment was given, the post-test result showed that the lower category was good and the highest category was very good. There ware ten students for good category $(32.25 \%)$ and for very good category, there was improvement from seven students $(22.58 \%)$ becomes twenty-one $(67.74 \%)$. It can be seen there were no students in fair, weak and poor category. So, it was concluded that PQRST technique gave much increasing on students' reading comprehension.

Moreover, in the control group, three phase technique was given as the treatment. Before the treatment was given for this group, the pre-test result showed that the lower category was fair and the highest category was very good with nine students $(29.03 \%)$ were in weak category and six students (19.35\%) were in very good category. But after treatment was given, the post-test result showed that there were still four students $(12.90 \%)$ were in fair category and for very good category, there was improvement from six students $(19.35 \%)$ becomes fifteen students (48.39\%). It can be seen the students' reading comprehension was increased by using three phase technique but the increasing was only little than using PQRST technique.

On the other hand, PQRST technique could help the students in reading comprehension. As the evidence, the first, when the research was conducted students could retell the content of the text in written, although only half of the story but in experimental group the students could not retell the text fast meanwhile they must understand the content of the text well. Only five until ten 
students understand the text well. The second, the timing more effective and did not need many review of the text in teaching learning process by using PQRST technique but in the experimental group the timing that is used can more because there is no parameter of the time. By using PQRST technique reading text organize well because the students must follow the step in order.

The usage of PQRST is good in reading comprehension. It is in line with previous study conducted by Vazquez et al (2006). They found that teaching of a course through the PQRST technique, both in English and Spanish, not only leads to fully satisfactory results but also that this techniques accepted by the majority of the students involved.

\section{CONCLUSION}

After conducting the research, some conclusion about the study of the effect of teaching reading by using PQRST technique is presented. The first, the result of the analysis indicated the mean score of students' reading comprehension by using PQRST technique was higher than the mean score of the students' reading comprehension not using PQRST technique. The second, the researcher has computed these two means score by using t-test formula; the value of t-test was higher than t-table. It is indicated that there was a significant difference on the students' reading comprehension that was taught by using PQRST technique. It meant that the effect of $\mathrm{PQRST}$ technique toward reading comprehension at SMAN 1 Kota Jambi was accepted.

\section{REFERENCES}

Ary, D et al. (2002). Introduction to Research in Education. (6 ${ }^{\text {th }}$ ed.). California: Wardsword.

Fahrurrazy. (2002). Pendekatan Kontruktivis untuk Pengajaran Reading Bahasa Inggris. Jurnal Pendidikan dan Pembelajaran. 9(1).

Fazel. (1993). How to Study Shoghi Effendi's Writings: Some notes on study skills and guides. Retrieved from se_writing.htm

Gay, L. R. (1992) Educational Research. New York: Maxwell, MacMillan International.

Nunan, D. (1993). Research Method in Language Learning. Cambridge: Cambridge University Press

Robinson, F. P. (1970). Effective study. New York: Harper \& Row.

Salkind, N. J. (1991). The role and important of research. New York: MacMillan Publishing Company.

Spache, G., \& Berg, P. (1978). The art of effective reading. (3rd ed.). New York: MacMillan. 
Sugiyono. (2008). Metode penelitian pendidikan (Pendekatan kuantitatif, kualitatif, dan $R \& D)$. Bandung: Alfabeta

Yuliana, E. (2007). Developing the First Year Students' Ability to Write Descriptive Text Paragraph through The Cubing Technique at SMAN 5 Kota Jambi. Unpublished Thesis. Jambi: FKIP, Jambi University

Vazquez, C. B., Green, R., \& Medina J. M. (2006). The application of the PQRST method to the teaching English of difficult or complex technological subjects. Jornadas De Innovacion Docente Universidad Europe De Madrid. 